\title{
PEMBERDAYAAN SANTRI MELALUI PENDIDIKAN ENTREPRENEURSHIP
}

\author{
Nurwadjah Ahmad EQ \\ Universitas Islam Negeri (UIN) Sunan Gunung Djati Bandung \\ Email: nurwadjah.ahmad@gmail.com \\ Andewi Suhartini \\ Universitas Islam Negeri (UIN) Sunan Gunung Djati Bandung \\ Email: andewi.suhartini@gmail.com
}

J. Sutarjo

Insitut Agama Islam Neberi (IAIN) Metro

Email: j.sutarjo@metrouniv.ac.id

\begin{abstract}
Global economic challenges especially in Asia it's enough to invite response some actors especially in Islamic education field at Islamic boarding school. Entrepreneurship education into something that is urgent in addition to knowledge of Islam itself. The students are prepared not only to be a scientist of Islam but also being an entrepreneur who is able to survive in the global competition in the economic field. The boarding school is able to supplement the curriculum with a variety of entrepreneurial activities such as trading, farming, herding fish, herding cow, herding goat, and home industry. This is an educational system that is not unusual during the time in the education boarding school in Indonesia.
\end{abstract}

Keywords: Santri, Entrepreneurship

\begin{abstract}
Abstrak
Tantangan ekonomi global terutama di Asia sudah cukup mengundang respons beberapa pelaku terutama di bidang pendidikan Islam di pondok pesantren. Pendidikan kewirausahaan menjadi sesuatu yang mendesak di samping pengetahuan Islam itu sendiri. Para siswa dipersiapkan tidak hanya untuk menjadi ilmuwan Islam tetapi juga menjadi wirausaha yang mampu bertahan dalam persaingan global di bidang ekonomi. Pesantren ini dapat melengkapi kurikulum dengan berbagai kegiatan wirausaha seperti perdagangan, bertani, menggiring ikan, menggembala sapi, menggembala kambing, dan industri rumahan. Ini adalah sistem pendidikan yang tidak biasa selama ini di sekolah berasrama pendidikan di Indonesia.
\end{abstract}

Kata Kunci: Santri, Kewirausahaan

\section{A. Pendahuluan}

Dunia pendidikan dewasa ini dihadapkan dengan berbagai persoalan yang semakin kompleks, salah satu persoalan yang menjadi tantangan yang sudah di depan mata diantaranya adalah adanya pencanangan MEA (Masyarakat Ekonomi Asean) pada awal tahun 2016. Pencanangan pasar tunggal yang lazim disebut dengan MEA ini selanjutnya akan menjadikan negara-negara di wilayah Asean dapat memasarkan produk dan jasa secara legal ke negara- 
negara lain di seluruh Asia Tenggara, dampaknya adalah persaingan akan semakin meningkat.

Situasi ini memunculkan kerisuan tersendiri bagi bangsa Indonesia khususnya, dikarenakan kompetisi yang sangat ketat yang akan terjadi, baik dalam produk yang dipasarkan maupun skill atau kualitas sumberdaya manusia yang dimiliki. Tidak mustahil jika produk-produk dalam negeri kalah dalam kualitasnya, dan akan digantikan dengan produk yang berasal dari luar negeri. Begitu juga dengan sumberdaya manusianya, jika skill atau jasa dan sumber daya manusia yang dimiliki rendah kualitasnya maka akan tergeser oleh tenagatenaga ahli dari negara-negara Asean lainnya. Untuk mengantisipasi dari ketertinggalan, perlu berbagai upaya yang dipersiapkan oleh semua pihak di masyarakat, salah satunya adalah dengan peningkatan kualitas produk, peningkatan profesionalitas kerja, serta mengembangkan berbagai usaha.

Dalam hal ini pemerintah sudah mempersiapkan sejak dini dalam menyongsong pasar tunggal tersebut, diantaranya yaitu dengan memunculkan program-program yang bertujuan untuk memberdayakan masyarakat, seperti yang tertuang dalam permendagri RI Nomor 7 Tahun 2007 tentang Kader Pemberdayaan Masyarakat, dinyatakan bahwa pemberdayaan masyarakat adalah suatu strategi yang digunakan dalam pembangunan masyarakat sebagai upaya untuk mewujudkan kemampuan dan kemandirian dalam kehidupan bermasyarakat, berbangsa dan bernegara (Pasal 1, ayat (8).

Berbagai upaya dalam pemberdayaan masyarakat pada saat ini sangat beraneka ragam bentuk dan macamnya, serta banyak dilakukan oleh seluruh elemen mayarakat, di antaranya yaitu lembaga swadaya masyarakat, perguruan tinggi, organisasi massa, organisasi politik, berbagai yayasan maupun lembagalembaga pendidikan.

Di negara yang sedang berkembang, peranan para wirausahawan adalah sangat penting terutama dalam penyelenggaraan pembangunan. Suatu bangsa dapat berkembang lebih cepat jika memiliki para wirausahawan yang memilki kreatifitas dan inovasi secara optimal yaitu dengan mewujudkan gagasangagasan baru yang dikonfersikan menjadi kegiatan yang nyata dalam setiap usahanya. Indonesia adalah salah satu negara yang sedang berkembang berusaha dengan giat dalam meningkatkan taraf hidup masyarakat. Sektor penting dalam meningkatkan taraf hidup rakyatnya adalah pendidikan. Pendidikan merupakan prasyarat untuk mempertahankan martabat manusia dan memiliki kesempatan dalam mengembangkan potensi dan membina kehidupan dalam masyarakat.

Dalam dunia pendidikan beberapa upaya sudah dilakukan untuk menyongsong adanya program MEA. Beberapa institusi/lembaga pendidikan berupaya untuk menghasilkan para lulusan/alumni yang memiliki kepribadian mandiri dan berjiwa entrepreneurship/wirausaha, sehingga mampu memainkan peran yang signifikan di tengah-tengah masyarakat sesuai dengan life skill yang 
dimiliki. Di antaranya adalah memberikan keterampilan/keahlian yang beragam sesuai dengan karakter yang ada di lingkungan sekolah tersebut.

\section{B. Pembahasan}

\section{Pengertian Pemberdayaan}

Kata pemberdayaan dalam bahasa Inggris "empowerment" yang juga dapat bermakna "pemberian kekuasaan" karena power bukan hanya sekedar "daya", melainkan juga berupa "kekuasaan", sehingga kata "daya" tidak saja bermakna "mampu", tetapi juga "mempunyai kuasa". Keberdayaan dalam konteks masyarakat (dalam hal ini masyarakat adalah santri pondok pesantren) adalah kemampuan individu yang bersenyawa dalam masyarakat dan membangun keberdayaan masyarakat yang bersangkutan. Masyarakat yang mayoritas anggotanya sehat fisik dan mental, terdidik dan kuat serta inovatif, pasti memiliki keberdayaan yang tinggi. Namun, selain kemampuan fisik, ada pula nilai-nilai intrinsik dalam masyarakat yang juga menjadi sumber keberdayaan seperti kekeluargaan, kegotongroyongan, kejuangan, dan yang khas pada masyarakat Indonesia, yaitu kebhinekaan. Seperti halnya pada masyarakat, begitu banyak yang memiliki kearifan lokal sehingga dapat menjadi modal dasar dalam kegiatan pemberdayaan masyarakatnya. ${ }^{1}$

Memberdayakan masyarakat adalah suatu upaya untuk meningkatkan harkat dan martabat bangsa Indonesia umumnya dan masyarakat khususnya yang dalam kondisi sekarang belum mampu melepaskan diri dari kemiskinan dan ketertinggalan. Dengan kata lain, memberdayakan adalah upaya memampukan dan memandirikan masyarakat. Dapat dikatakan bahwa pemberdayaan merupakan sebuah "proses menjadi" bukan sebuah "proses instan". Sebagai proses, pemberdayaan mempunyai tiga tahapan yaitu, penyadaran, pengkapasitasan dan pendayaan.

Pemberdayaan dapat dijelaskan sebagai berikut. Pada tahap pertama adalah upaya penyadaran. Pada tahap ini target yang hendak diberdayakan melaui pemebrian "pencerahan" dalam bentuk penyadaran bahwa mereka mempunyai hak untuk memiliki "sesuatu". Seperti, targetnya adalah kelompok masyarakat miskin. Kepada mereka diberikan pemahaman bahwa mereka dapat menjadi orang-orang berada, dan itu dapat dilakukan jika mereka mempunyai kapasitas untuk keluar dari kemiskinan. Kegiatan yang dapat dilakukan pada tahap ini misalnya dalam bentuj pemberikan pengetahuan yang bersifat kognisi (wawasan/ pengetahuan), belief (rasa percaya diri), dan healing (solusi). Prinsip dasarnya adalah membuat target mengerti bahwa mereka perlu membangun "demand" (permintaan) untuk diberdayakan dan proses pemberdayaan itu dimulai dari dalam diri mereka sendiri bukan dari orang lain.

1 Wrihatnolo, Randi \& Dwitjoto, Rian Nugroho, Manajemen pemberdayaan sebuah pengantar dan panduan untuk pemberdayaan masyarakat, (Jakarta: Elex Media, 2007) h. 1. 
Tahap kedua adalah pengkapasitasan. Inilah yang sering disebut dengan capacity building, atau dalam bahasa yang lebih sederhana memampukan atau enabling. Untuk diberikan daya atau kuasa, yang bersangkutan harus mampu terlebih dahulu. Misalnya, sebelum memberikan otonomi daerah, seharusnya daerah-daerah yang hendak diotonomkan diberi program pemampuan atau capacity building untuk membuat mereka "cakap" (skilfull) dalam mengelola otonomi yang diberikan. Proses capacity building terdiri atas tiga jenis, yaitu manusia, organisasi, dan sistem nilai.

Tahap ketiga adalah pemberian daya itu sendiri - atau empowerment dalam makna sempit. Pada tahap ini target diberikan daya, kekuasaan, otoritas, atau peluang. Pemberian ini sesuai dengan kualitas kecakapan yang telah dimiliki. $^{2}$

\section{Pengertian Santri}

Istilah santri di Indonesia yang sudah sangat popular khususnya di kalangan umat Islam. Hal ini tentu dikarenakan oleh eksistensi pondok pesantren yang sudah ratusan tahun dan sudah melahirkan banyak tokoh bangsa sekaligus membentuk karakter bangsa Indonesia. Kata "Pesantren", yang menurut para ahli adalah sebuah tempat perkumpulan para santri, atau secara segi bahasa pesantren sendiri merupakan kata serapan dari santri itu sendiri dengan menambahkan tambahan pe-di awalnya dan -an diakhirnya, yang bisa disimpulkan asal katanya ialah pesantrian, sehingga bertransformatif menjadi pesantren. ${ }^{3}$

Kata santri sendiri didefinisan dalam Wikipedia sebagai sebutan bagi seseorang yang mengikuti pendidikan Ilmu Agama Islam di suatu tempat yang dinamakan Pesantren, biasanya menetap di tempat tersebut hingga pendidikannya selesai. ${ }^{4}$ Definisi ini tentu sangat diterima kendatipun di lapangan santri sendiri terbagi menjadi dua; ada santri yang menetap di pondok pesantren dan ada santri yang ke pesantren hanya ketika mengikuti kegiatan di pesantren sementara tempat tinggal tetap dengan keluarga karena lokasi berdekatan dengan pesantren dan lazin disebut sebagai "santri kalong (kelelawar)".

\section{Pendidikan Entrepreneurship}

\section{a. Pengertian Pendidikan}

Kata pendidikan berasal dari kata didik, lalu kata ini mendapat awalan kata "me" sehingga menjadi mendidik artinya memelihara dan memberi latihan. Dalam memelihara dan memberi latihan diperlukan adanya ajaran, tuntutan dan pimpinan mengenai akhlak dan kecerdasan pikiran. Kata pendidikan yang

\footnotetext{
2 Wrihatnolo, Randi \& Dwitjoto, Rian Nugroho, Manajemen pemberdayaan..., h. 2.

3 https://hafizhuddin30.wordpress.com/2015/10/25/definisi-dan-makna-santri-sebuah-

4 https://id.wikipedia.org/wiki/Santri.
} pengantar. 
digunakan sekarang, dalam bahasa Arabnya adalah tarbiyah, dengan kata kerja rabba. Kata pengajaran dalam bahasa Arabnya adalah ta'lim dengan kata kerjanya 'allama. Pendidikan dan pengajaran dalam bahasa Arab adalah tarbiyah wa ta'lim. Sedangkan pendidikan Islam dalam bahasa Arabnya adalah Tabiyah Islamiyah. ${ }^{5}$

Dalam Undang-Undang Tahun 2003 Tentang Sistem Pendidikan Nasional dinyatakan bahwa "Pendidikan adalah usaha sadar dan terencana untuk mewujudkan suasana belajar dan proses pembelajaran agar peserta didik secara aktif mengembangkan potensi dirinya untuk memiliki kekuatan spiritual keagamaan, pengendalian diri, kepribadian, kecerdasan, akhlak mulia, serta ketrampilan yang diperlukan dirinya, masyarakat, bangsa dan negera. ${ }^{6}$

Adapun pengertian pendidikan dari segi istilah, dapat merujuk kepada berbagai sumber yang diberikan para ahli yaitu bahwa pendidikan adalah memberi pertolongan secara sadar dan sengaja kepada seorang anak (yang belum dewasa) dalam pertumbuhannya menuju ke arah kedewasaan, dalam arti dapat berdiri dan bertanggung jawab susila atas segala tindakan-tindakannya menurut pilihannya sendiri.

\section{b. Pengertian Entrepreneurship}

Pada umumnya pengertian-pengertian yang ada dari berbagai para ahli menyatakan bahwa, wirausaha adalah seorang yang memilki potensi dalam melihat peluang mencari dana, dan sumber dana lain yang diperlukan untuk meraih peluang tersebut dan berani mengambil resikonya dengan tujuan tercapainya kesejahteraan individu dan nilai tambah bagi masyarakat. Menurut Dun Steinhoff dan John F. Burgess wirausaha merupakan orang yang mengorganisasikan, mengelola, dan berani menanggung resiko untuk menciptakan usaha baru dan peluang berusaha. ${ }^{7}$ Sedangkan dalam konteks manajemen pengertian entrepreneur adalah seorang yang memiliki kemampuan dalam mengunakan sumber daya seperti financial (money) ,bahan mentah (matrials),dan tenaga kerja (labors), untuk menghasilkan produk baru,bisnis baru, proses produksi atau pengembangan organisasi usaha ${ }^{8}$

Makna kewirausahaan sendiri selanjutnya berkembang seiring dengan evolusi pemikiran para pakar ekonomi di dunia Barat, kemudian menyebar ke negara-negara lain, termasuk ke Indonesia. Di Indonesia, konsep entrepreneurship tersebut diterjemahkan sebagai kewiraswastaan dan kewirausahaan, sementara entrepreneur sebagai pelakunya yaitu wirausaha. Menurut Kemendiknas, kewirausahaan adalah suatu sikap jiwa dan kemampuan untuk menciptakan

${ }^{5}$ Zakiah Darajat,dkk, Ilmu pendidikan, (Jakarta: Bumi Aksara,2009), h. 25-28.

6 Undang undang Nomor 20 Tahun 2003 Tentang sistem Pendidikan Nasional Bab 1 Pasal 1.

7 Yuyus Suryana dan Kartib Bayu, Kewirausahaan Pendekatan Karakteristik wirausahawan Sukses, (Jakarta: Kencana, 2011), h. 27.

8 Mudjiarto Aliaras Wahid, Membangun Karakter dan Kepribadian Kewirausahaan, (Yogyakarta: Graha Ilmu, 2006), h. 2. 
sesuatu yang baru, yang sangat bernilai dan berguna, baik bagi dirinya sendiri maupun bagi orang lain.

Sifat wirausaha adalah orang yang mendobrak system ekonomi yang ada dengan memperkenalkan barang dan jasa yang baru, dengan menciptakan bentuk organisasi baru atau mengolah bahan baku baru. Dengan demikian orang tersebut melakukan kegiatannya melalui organisasi bisnis yang baru ataupun bisa pula dilakukan dalam organisasi bisnis yang sudah ada. Dalam definisi ini ditekankan bahwa seorang wirausaha adalah orang yang mengetahui peluang kemudian menciptakan sebuah organisasi untukmemanfaatkan peluang tersebut. Pengertian wirausaha di sinimenekankan pada setiap orang yang memulai sesuatu bisnis yang baru. Sedangkan proses kewirausahaan meliputi semua kegiatan fungsi dan tindakan untuk mengejar dan memanfaatkan peluang dengan menciptakan suatu organisasi. ${ }^{9}$

Menjadi seorang entrepreneur berarti memadukan perwatakan pribadi, keuangan dan sumber-sumber daya di dalam lingkungan. Menjadi entrepreneur berarti memiliki kemampuan menemukan dan mengevaluasi peluang-peluang, mengumpulkan sumber-sumber daya yang diperlukan dan bertindak untuk memperoleh keuntungan dari peluangpeluang itu. Para entrepreneur merupakan pemimpin dan mereka menunjukkan sifat kepemimpinan dalam pelaksanaan sebagian besar kegiatan-kegiatan mereka. Mereka mengambil risiko yang telah diperhitungkan dan menyukai tantangan dengan risiko moderat. Para entrepreneur percaya teguh pada dirinya dan kemampuannya dalam mengambil keputusan yang tepat. Kemampuan mengambil keputusan inilah yang merupakan ciri khas para entrepreneur. ${ }^{10}$ Disamping itu semua yang tidak kalah pentingnya dari kemampuan seorang entrepreneur yaitu kemampuan dalam memanajemen dan menggunakan waktu secara efektif.

Jadi pengertian entrepreneur menurut penulis adalah individu-individu yang berorientasi pada tindakan dan bermotivasi tinggi untuk mandiri dengan berani mengambil risiko dalam mengejar tujuannya. Sifat kemandirian yang dimilikinya akan sangat berguna dalam menjalankan kepemimpinannya terutama dalam mengambil suatu keputusan dan kemauan bertanggungjawab atas tindakannya.

\section{c. Ciri-ciri Khusus Entrepreneur}

Adapun ciri khusus yang harus dimiliki oleh seorang entrepreneur/wirausahawan adalah sebagai berikut: 11

1) Mempuyai mimpi mimpi yang realistis dan tinggi yang mampu diubah menjadi cita cita yang harus ia capai. Hidup ingin berubah karena

${ }_{9}$ Bukhori Alma, Kewirausahaan, ( Bandung: Alfabeta, 2010), h. 24.

10 Geoffreg G Meredith, Kewirausahaan Teori dan Praktek, Penterjemah: Andre Asparsayogi (Jakarta: PPMI, 2000), h. 4.

${ }^{11}$ Hendro, Dasar-Dasar Kewirausahaan, (Jakarta: Erlangga, 2011), h. 45. 
kekuaan emosianalnya yang tinggi dan keyakinannya yang kuat, sehingga mimpi itu bisa terwujud (power of dream).

2) Mempuyai empat karakter dasar kekuatan emosianal yang saling mendukung untuk sukses: Determenasi, persistence, keberanian, struggle.

3) Menyukai tantangan dan tidak pernah puas dengan apa yang di dapat.

4) Mempuyai tantangan dan tidak puas dengan apa yang didapat.

5) Memiliki keyakinan yang kuat akan kemampuanya bahwa "dia bisa.

6) Seorang yang visioner dan mempunyai daya kreativitas yang tinggi.

7) Risk manager, not just risk taker.

8) Memiliki strong emotional attachment (kekuatan emosional).

9) Seorang problem solver.

10) Mampu menjual dan memasarkan produknya (seller).

11) Ia mudah bosan dan terkesan sulit diatur.

12) Seorang kreator ulung.

\section{d. Karakteristik Kewirausahaan}

David Mc Clelland menyatakan ada 9 karakteristik utama yang terdapat dalam diri seorang wirausaha sebagai berikut: ${ }^{12}$

1) Dorongan berprestasi: semua wirausahawan yang berhasil memiliki keinginan besar untuk mencapai suatu prestasi.

2) Bekerja keras; sebagian besar wirausahawan mabuk kerja demi mencapai sasaran yang ingin dicita citakan.

3) Memperhatikan kualitas; wirausahawan menangani dan mengawasi sendiri bisnisnya sampai mandiri sebelum dia memulai dengan usaha baru lagi.

4) Sangat bertanggung jawab; wirausahawan sangat bertanggung jawab atas usaha mereka, baik secara moral, legal, maupun mental.

5) Berorientasi pada imbalan; wirausahawan mau berprestasi ,kerja keras dan bertanggung jawab, dan mereka menerapkan imbalan yang sepadan dan berorientasi pada imbalan; wirausahawan mau berprestasi ,kerja keras dan bertanggung jawab, dan mereka menerapkan imbalan yang sepadan dengan usaha. Imbalan itu tidak hanya berupa uang tetapi juga pengakuan dan penghormatan.

6) Optimis; Wirausahawan hidup dengan doktrin semua waktu baik untuk bisnis, dan segala sesuatu mungkin.

7) Berorientasi pada hasil karya yang baik.

8) Mampu mengorganisasikan.

Berorientasi pada uang. Uang yang dikejar oleh para wirausahawan tidak semata mata hanya untuk memenuhi kebutuhan pribadi dan pengembangan usaha saja, tetapi juga dilihat sebagai ukuran prestasi kerja dan keberhasilan.

12 Mudjiarto Aliaras Wahid, Membangun Karakter..., h. 3-4. 


\section{e. Pendidikan Entrepreneurship di Pondok Pesantren.}

Dalam pengembangan pesantren, misi utamanya adalah menciptakan kader ulama, konsentrasinya adalah program Tafaqquh Fiddin dan solusinya adalah melalui program Pendidikan Diniyah Formal.

Disamping itu ada tujuh program prioritas yang akan dilaksanakan pada tahun 2015, Program 10.000 Hafizh Al-Quran, Pendidikan Kader Ulama. Program Takhasus Tafaqquhfiddin, Pengembangan Pesantren berwawasan Bahari. Pengembangan lifeskill dan Enterpreneurship, Pendidikan Keagamaan Terpadu di Daerah P3T (Tertinggal, Terluar dan Terdepan), terakhir Kemitraan Lembaga. Untuk mensukseskan program tersebut, perlu adanya dukungan seluruh elemen pemangku kebijakan, termasuk kepala bidang PAKIS seluruh Indonesia. Oleh karena itu, jalinan kerjasama yang kuat antara pusat dan daerah dalam mendukung program dan anggaran menjadi keniscayaan, sehingga tujuan program pengembangan pesantren tersebut dapat tercapai. ${ }^{13}$

Pada saat ini peran strategis pondok pesantren yang diharapkan dapat menjadi mitra pemerintah dalam pemberdayaan ekonomi kerakyatan.Karena pondok pesantren pada umumnya lahir dan berbasis di daerah-daerah pedesaan yang masyarakatnya masih memegang teguh sikap gotong royong dan kekeluargaan. Keberadaan pondok pesantren di masyarakat mempunyai peran yang sangat strategis dalam pendidikan, yang sangat mengakar di masyarakat menjadi kekuatan tersendiri dalam membangkitkan semangat masyarakat untuk mencapai kemajuan dan kehidupan yang lebih sejahtera.

Di samping berfungsi dan berperan sebagai agen pemberdayaan masyarakat untuk berpartisipasi aktif dalam pembangunan, pondok pesantren diharapkan juga mampu memberdayakan diri agar mandiri, terutama dalam aktifitas ekonomi.

\section{Program Entrepreneurship di Pondok Pesantren}

Dalam upaya pengembangan pesantren di Indonesia, Direktorat pendidikan madrasah dan pondok pesantren mengembalikan kemandirian pondok pesantren melalui dua aspek yaitu; Menciptakan kewirausahaan pada pondok pesantren dan memberikan keterampilan kepada para santri. Program enterpreneur di pondok pesantren adalah sebagai salah satu program yang digunakan sebagai alternatif untuk melatih jiwa santri sehingga bisa memiliki jiwa wirausahawan yang salah satunya adalah memiliki rasa mandiri atau tidak selalu merasa ketergantungan dengan orang lain. Program ini dijadikan sebagai salah satu cara untuk memenuhi kebutuhan santri sehari-hari, biaya operasional pondok pesantren maupun biaya operasional pendidikan formal mereka.

13http:/ / ditpdpontren.kemenag.go.id/direktur-menyapa/direktur-pd-pontrensingkronisasi-program-menjadi-keharusan/, diakses pada tanggal 22 September 2015, pukul 09.30. 
Mendidik anak untuk mempunyai watak jiwa wirausaha tidaklah mudah, sering kali rasa takut gagal, gengsi dan tidak percaya diri menghantui diri seseorang. Untuk mengatasi hal tersebut, hendaknya membuka program pelatihan entrepreneur dengan tujuan selain untuk melatih jiwa santri menjadi semangat berproduksi, program tersebut bertujuan untuk sumber pendapatan pesantren, Dengan adanya kegiatan wirausaha setiap harinya, diharapkan semua kebutuhan santri dan pimpinan pondok pesantren (Kiyai) dapat terpenuhi. Demikian hasil atau manfaat yang diperoleh dari kegiatan ini dan dapat dirasakan sangat membantu dan bermanfaat, terutama untuk santri.

\section{Jenis-Jenis Kegiatan Entrepreneurship di Pondok Pesantren}

Kegiatan yang termasuk dalam program entrepreneur yang dilaksanakan di pesantren, dilaksanakan dengan cara bertahap, jika satu program sudah berjalan dengan baik, maka akan dikembangkan lagi kegiatan-kegiatan yang lainnya dan terus akan berkembang sesuai dengan kebutuhan dan kemampuan yang ada.

Adapun kegiatan yang mungkin dalam program entrepreneurship di pesantren ini di antaranya adalah:

\section{a. Perdagangan.}

Perdagangan yang ada disini adalah berupa pemasaran produk-produk yang dihasilkan para santri. Produk-produk tersebut meliputi usaha pengolahan kedelai menjadi beberapa olahan, kemudian dari kedelai tersebut dibuat susu kedelai yang biasa orang menyebut sule. Bila seseorang tidak boleh atau tidak dapat makan daging atau sumber protein hewani lainnya, kebutuhan protein sebesar 55 gram per hari dapat dipenuhi dengan makanan atau minuman yang berasal dari 157,14 gram kedelai. ${ }^{14}$ ada pula olahan kedelai tersebut menjadi nugget. Nugget adalah suatu bentuk produk olahan daging yang terbuat dari daging giling yang dicetak dalam bentuk potongan empat persegi dan dilapisi dengan tepung berbumbu.

Memang pada umumnya nuggets kebanyakan berbahan dasar daging, baik ayam ataupun ikan.alternatif terbaru nugget nabati berbahan dasar kedelai ini memiliki protein tinggi. Biasanya, ampas tahu hanya dijual oleh pemilik pabrik tahu dan digunakan untuk campuran makanan ternak, utamanya sapi. Namun, siapa sangka limbah tahu dapat dijadikan makanan berupa nugget yang memiliki nilai gizi tinggi dan aman dikonsumsi anak-anak. Pasalnya, meski limbah ternyata pada ampas tahu masih mengandung protein dan karbohidrat. ${ }^{15}$

14 http://bisnisukm.com/peluang-usaha-berbagai-macam-olahan-kedelai.html, diakses pada tanggal 25 Agustus 2015.Pukul 11.00.

${ }^{15}$ Kreasi inilah yang dilakukan oleh para santri dan pelajar SMK Integral Minhajut Tullab Pekalongan Lampung Timur, yang memanfaatkan limbah tahu untuk dijadikan nugget, hal ini dilakukan supaya tidak ada yg mubadzir dari sisa pengolahan tersebut. Semua produk yang dihasilkan tersebut dipasarkan oleh para santri pada waktu pagi hari di toko-toko dan perumahan 
Dari kegiatan tersebut di atas, ada dua keuntungan dalam bidang kewirausahaan yang bisa diperoleh para santri, yaitu mendapatkan pengetahuan dan keterampilan tentang pembuatan susu kedelai dan nugget, serta mendapatkan pengetahuan dan keterampilan tentang bagaimana memasarkan barang kepada konsumen.

\section{b. Perikanan}

Untuk kegiatan budidaya ikandapat dibuat beberapa kolam ikan, kegiatan perikanan yang dilakukan oleh para santri hanya sebatas pembesaran tanpa memperbanyak atau pengembangbiakan. Untuk bibit ikan, para santri dapat membeli dari daerah-daerah yang menyediakan bibit ikan, kemudian dibesarkan di kolam-kolam. Adapun jenis ikan yang dapat diternak ternak di antaranya adalah ikan nila. Karena ikan nila pertumbuhannya tidak terlalu lama, hanya menunggu empat bulan ikan nila siap untuk dipanen. Disamping ikan nila juga ada ikan lele dan gurame, Setelah dipanen, ikan tersebut dijual kepada pedagang-pedagang ikan atau konsumen-konsumen yang ada di daerah sekitar pondok pesantren. Pengetahuan serta keterampilan dalam budidaya ikan sangat penting, karena dalam memelihara ikan tidaklah mudah, ada hal-hal yang perlu diketahui agar ikan tidak banyak mati dan cepat besar. Dalam program budidaya ikan ini, para santri mendapat pengetahuan tentang cara memelihara ikan dan ilmu tentang cara pemasarannya.

\section{c. Pertanian}

Metode pertanian yang dapat digunakan para santri adalah sistem tumpangsari, yaitu usaha pertanian untuk menanam beberapa jenis tanaman pada sebidang tanah. Adapun jenis tanaman yang ditanam adalah sayur mayur dan dan ubi-ubian (Bayam, Kacang panjang, Kangkung, Ubi Jalar, singkong, dll) dengan lahan tidak terlalu luas kurang lebih setengah hektar mampu digunakan untuk lahan yang produktif. Dalam program pertanian ini para santri dididik untuk terampil dalam memanfaatkan lahan yang kosong, sehingga bisa dimanfaatkan untuk menanam sesuatu yang bermanfaat bagi dirinya dan bahkan bisa menghasilkan pendapatan tambahan.

\section{d. Peternakan}

Dalam bidang peternakan, para santri dapat diberi bekal bagaimana merawat, membesarkan dan sekaligus memasarkan binatang ternak hasil peliharaannya. Adapun program peternakan yang dapat dikembangkan adalah peternakan kambing, sapi, kerbau, ayam dan lain-lain. Tujuan dari program peternakan ini adalah untuk melatih para santri tentang bagaimana beternak

warga yang ada di sekitar pondok pesantren tersebut, sebagian dengan mengendarai motor dan sebagian lagi dengan berjalan kaki. 
yang baik, sehingga menghasilkan hewan ternak yang berkualitas (gemuk dan sehat) dan bagaimana memasarkan hasil ternaknya kepada pedagang atau konsumen yang ada.

Semua kegiatan tersebut di atas dilakukan oleh semua santri, adapun waktu yang dapat mereka manfaatkan untuk melaksanakan kegiatan enterpreneur ini sangat terbatas karena kegiatan ini hanya sebatas sampingan untuk memenuhi kebutuhan dan opersional pendidikan mereka. Para santri hanya dapat memulainya setelah subuh hingga pukul 8.00 WIB. mereka harus bersiap-siap untuk berangkat melanjutkan kegiatan belajar formal untuk menunjang bidang akademisi mereka. Setiap pagi setelah selesai menunaikan sholat Shubuh, para santri yang mendapat bagian pertanian, mereka langsung terjun ke lahan pertanian, ada yang bagiannya menyangkul, membersihkan rumput, memupuk, menyemprot memetik sayuran yang sudah layak dipetik dll. Sedangkan yang mendapat tugas pengolahan sule, nuget, dan pengolahan kecap Mereka bergegas sesuai tugasnya masing-masing tanpa harus diperintah lagi. Begitu pula ketika pagi mulai cerah, para santri berkeliling ke masyarakat setempat untuk menjual produk-produk mereka dengan mendatangi dari satu ke rumah lainnya tanpa ada rasa gengsi selagi hal itu halal. Mereka harus kembali pada pukul 08.00 tepat guna mempersiapkan pendidikan formal mereka karena waktu masuk pendidikan formal pukul 08.30 WIB. 16

\section{Kebutuhan dalam Program Entrepreneurship}

Program entrepreneurship yang lakukan di pondok pesantren tentunya tidak terlepas dari berbagai kebutuhan untuk mendukung. Dari ketiga sektor itu yang pertama masalah penjualan. Pada bagian perikanan kendalanya yang sering dihadapi para santri adalah masalah pembinaan. Sumber dana untuk modal operasional. Untuk mengoptimalkan kegiatan entrepreneur ini yang pertama diberikan suntikan modal.

Selanjutnya kebutuhan terkait dengan pengaturan waktu pelaksanaan kegiatan entrepreneurship. Padatnya pembelajaran di pondok pesantren hendaknya dapat atur sedemikian rupa supaya kegiatan entrepreneurship dapat berjalan dan menghasilkan keuntungan sebagaimana yang diharapkan. Di antara cara pengaturan waktu adalah membuat jadwal piket santri yang bertanggung jawab mengurusi usaha-usaha yang ada di pondok pesantren.

\section{Simpulan}

Dari uraian-uraian mengenai gagasan tentang pemberdayaan santri melalui Pendidikan entrepreneurship dapat ditarik kesimpulan yaitu bahwa, kegiatan entrepreneurship dapat dilakukan di pondok pesantren dengan tetap mengutamakan tafaqquh fi addin (memperdalam ilmu-ilmu agama) karena tujuan utama belajar di pondok pesantren adalah untuk mendalami ilmu-ilmu atau

16 Studi Kasus di Pondok Pesantren Minhajut Tulab Pekalongan Lampung Timur. 
pengetahuan tentang agama Islam. Adapun jiwa wirausaha adalah sebagai pelengkap yaitu terutama santri memiliki jiwa berdikari atau mandiri terutama dalam bidang kewirausahaan. Selanjutnya, pendidikan entrepreneurship di pondok pesantren bertujuan untuk menciptakan santri yang mempunyai jiwa wirausahawan. Kemampuan dan keberanian untuk melakukan suatu usaha dalam meraih keuntungan yang bersifat ekonomis membutuhkan latihan dan pembiasaan. Dengan kegiatan pengelolaan usaha diharapkan akan tumbuh dan melekat mental yang berani melakukan kegiatan-kegiatan wirausaha. Namun yang harus ditekankan yaitu pola pendidikan entrepreneurship yang ada di pondok pesantren hendaknya sesuai dengan landasan serta tujuan yang ada di beberapa teori tentang pendidikan entrepreneurship. Baiknya dalam menjalankan kegiatan wirausaha dipandu oleh teori-teori yang berkaitan dengan wirausaha. Hal ini diharapkan wirausaha yang dilakukan tidak sia-sia dalam artian akan memberikan keuntungan-keuntungan yang signifikan yang dapat dimanfaatkan oleh santri khususnya dan pondok pesantren pada umumnya. Disamping itu, pengaturan waktu dalam melaksanakan kegiatan entrepreneurship dapat dilakukan dengan pembagian tugas misalnya dalam bentuk piket secara bergantian. Kembali pada tujuan utama dari kegiatan Pendidikan entrepreneurship merupakan tambahan atau pelengkap maka waktu belajar mendalami ilmu-ilmu agama hendaknya tetap menjadi prioritas bagi santri. Selebihnya baru dimanfaatkan untuk kegiatan pengembangan Pendidikan entrepreneurship.

\section{Referensi}

Bukhori Alma, Kewirausahaan, ( Bandung: Alfabeta, 2010)

Hendro, Dasar-Dasar Kewirausahaan, (Jakarta: Erlangga, 2011)

Geoffreg G Meredith, Kewirausahaan Teori dan Praktek, Penterjemah: AndreAsparsayogi (Jakarta: PPMI,2000)

http:/ / ditpdpontren.kemenag.go.id/direktur-menyapa/direktur-pd-pontrensingkronisasi-program-menjadi-keharusan/, diakses pada tanggal 22 September 2015, pukul 09.30

http:/ / bisnisukm.com/peluang-usaha-berbagai-macam-olahan-kedelai.html), diakses pada tanggal 25 Agustus 2015.Pukul 11.00.

https://id.wikipedia.org/wiki/Santri

https://hafizhuddin30.wordpress.com/2015/10/25/definisi-dan-makna-santrisebuah-pengantar,diakses pada tanggal 22 September 2015

Mudjiarto Aliaras Wahid, Membangun Karakter dan Kepribadian Kewirausahaan, (Yogyakarta: Graha Ilmu, 2006)

Undang undang Nomor 20 Tahun 2003 Tentang sistem Pendidikan Nasional Bab 1 Pasal 1. 
Wrihatnolo, Randy R \& Riant Nugroho Dwidjowijoto. 2007. Manajemen Pemberdayaan. Sebuah Pengantar dan Panduan untuk Pemberdayaan Elex Media. Jakarta: 2007)

Yuyus Suryana dan Kartib Bayu, Kewirausahaan Pendekatan Karakteristik wirausahawan Sukses, (Jakarta: Kencana, 2011)

Zakiah Darajat, dkk, Ilmu pendidikan, (Jakarta: Bumi Aksara, 2009) 